\title{
A proposed smart market design for sediment discharge
}

\author{
Antonio A. Pinto ${ }^{\text {a }}$, John F. Raffensperger ${ }^{\mathrm{b}}$, Thomas A. Cochrane ${ }^{\mathrm{c}}$, and E. Grant Read ${ }^{\mathrm{d}}$
}

\begin{abstract}
Sediment discharge from erosion, urban run-off, and construction can cause environmental degradation. Governments try to regulate sediment, but the regulatory approach is costly to land owners. In principle, a market-based system could reduce costs, but the associated transaction costs are far too high, as market participants must find trading partners, negotiate, and seek government approval.
\end{abstract}

In this paper, we propose a smart market design with an associated market clearing model for sediment discharge. Market participants bid for and offer tradable discharge allowances to a central auctioneer. The allowances correspond to kilograms of sediment discharge per year, as estimated by an erosion model. The auctioneer then uses a linear program to price and allocate sediment allowances in a given catchment. Participants do not trade bilaterally, but rather through a central pool, reducing transaction costs. The market design can use all available relevant hydrological data, quantifies environmental effects explicitly, and gives price signals based on the environmental features. Additionally, the initial rights could be scaled back or up when catchment is over or under-allocated to keep a market operator with revenue neutrality. We simulate the smart market for two catchments in Auckland, New Zealand.

Key words: Sediment discharge, market, erosion, scaling rights, linear programming.

a Department of Management, University of Canterbury, Christchurch, New Zealand. Email antonio.pinto@pg.canterbury.ac.nz. Private bag 4800, Christchurch 8140. Phone +64 3 3642987, Fax +64 3 3642020 .

b Department of Management, University of Canterbury, Christchurch, New Zealand. Email john.raffensperger@canterbury.ac.nz. Private bag 4800, Christchurch 8140. Phone +64 3 3642987, Fax +64 3 3642020 .

c Department of Civil and Natural Resources Engineering, Christchurch, University of Canterbury, New Zealand. Email tom.cochrane@canterbury.ac.nz. Private bag 4800, Christchurch 8140. Phone +64 3 3642378, Fax +64 3 3642758.

d Department of Management, University of Canterbury, Christchurch, New Zealand. Email grant.read@canterbury.ac.nz. Private bag 4800, Christchurch 8140. Phone +64 3 3642987, Fax +64 33642020. 


\section{Introduction}

Excess and contaminated sediments damage the ecology of waterways and estuaries (Ribaudo et al. 1999; Strappazzon et al. 2003; Tang et al. 2005; Westra et al. 2005; Hill et al. 2007; Pappas et al. 2008). Environmental impacts may include the loss of fish, wildlife populations and habitat. Contaminant-laden sediment threatens the viability of ports, due to the high costs of disposal of the dredged sediments. Many studies have recommended nonmarket instruments to manage sediments, such as voluntary programming initiatives, command and control, and financial incentives to use best management practices (BMPs), but these approaches have been criticized as both inefficient and ineffective.

Tradable instruments are being used for $\mathrm{SO}_{x}, \mathrm{CO}_{2}, \mathrm{NO}_{\mathrm{x}}$, fishery quotas, and water rights (Tinbergen 1956; Montgomery 1972; Ribaudo et al. 1999; Colby 2000; Woodward and Kaiser 2002; Stavins 2004; Tietenberg 2006; Shortle and Horan 2008; Garrick et al. 2009). Montgomery (1972) presented a static framework of a market for emission and pollution licenses. He defined emissions licenses as the right to discharge from the source and pollution licenses as the right to emit into a receptor point. The main point was that pollution licenses would be more suitable as tradable instruments than emission licenses. Unfortunately, pollution licenses are not suitable with many receptors due to high transaction costs. Participants would need a separate pollution license for each receptor, so a market would be almost impossible to clear. Additionally, strategic decisions by participants in dealing with separate pollution licenses may enable gaming which would reduce market efficiency. Ermoliev et al. (2000) discussed different trade mechanisms for pollution permit markets. They noted that a bilateral market may converge only with a few receptors. Thus, a traditional market with many receptors would have problems with convergence and high transaction costs. Cronshaw and Kruse (1996) extended Montgomery's work and proposed a dynamic analysis with a banking system and a fixed planning horizon. The authors faced the difficulties 
of choosing the length of the planning horizon, complexity in clearing a market with multiple receptors, and the inter-temporal impact effects over a long planning horizon.

Ribaudo et al. (1999) from a view of non-point sources pollution reviewed water quality policies and analyzed policy instruments from areas such as economic incentives, liability and future research. They pointed out that market based instruments should require government intervention when externalities are an issue. Garrick et al. (2009) presented a conceptual framework for policy reform in environmental water quality market. The authors focused the analysis on legal and regulatory aspects, and used two case studies: the Columbia (USA) and Murray-Darling (Australia) for comparing the design of the markets.

Shortle and Horan (2001) described the economics of non-point pollution control. They noticed that policies in the USA are focused on emission proxies, pollution levels and ambient concentrations; to reach environmental targets cost-effectively, policy makers should address stochasticity, trading ratios and monitoring. Shortle and Horan (2008) extended their review about quality trading and focused on aspects such as the definition of the commodity, the market rules, especially the exchange ratios between point and non-point sources, and setting of environmental caps. In particular, the authors addressed stochasticity, observing that nonpoint source emissions are inherently riskier than point source emissions. The authors pointed out problems with a bilateral trading scheme and the associated transaction costs. Woodward and Kaiser (2002) reviewed water quality trading in the USA: exchanges, bilateral programs, clearing houses and sole-source offsets. The authors noticed that none is cost-efficient and environmentally effective because the commodities are non-uniform and transaction costs (monitoring, bargaining, searching, and information) are high.

McCann et al. (2005) reviewed transaction cost concepts and typologies, and identified reasons that make market-based policies fail. The authors pointed out that transaction costs are high in most environmental market-based instruments. Netusil and Braden (2001) evaluated 
the reduced gains from trade due to transaction costs with transferable sediment discharge permits in a bilateral market. The author noticed that the transaction costs increased the total cost of achieving an overall load target.

Tisdell (2007) evaluated different instruments to reduce sediment discharge in a catchment. The author tested cap and trade with simple closed auctions, auctions with first and second prices, and command and control policy. Command and control proved to be least efficient, and strategic gaming decisions were observed with first and second price auctions. A cap and trade system with auctions converged to an efficient outcome, obtaining the minimum cost to reduce emission via tradable credits. In theory, tradable credits should achieve the same costminimizing allocations as controls imposed by optimal Pigovian taxes (Stavins 2004).

McCabe et al. $(1989 ; 1991)$ demonstrated that an auction cleared with the help of an optimization model allows management of complexities and third-party effects of trades (such as the multiple receptors and sediment transport coefficients in our case) that are not possible with an ordinary auction. This optimization-based auction is called a "smart market". Smart markets are currently in active use in electricity and gas. Hogan et al. (1996) presented a linear model (LP) to obtain spot prices in an electricity market. The market operator calculates the optimum dispatch based on bids from participants. Prices vary spatially over the network, depending on constraints in the power system. McCabe et al. $(1989 ; 1991)$ designed a computer-assisted market for natural gas, as a sealed bid auction. The wholesale market coordinated trade from pipeline sources to delivery points in a network. Participants would submit locational offers/demands in the auction, and an optimization model would clear the market, maximizing the total surplus of trade, with transport capacities as constraints. The model would calculate allocations and prices for all participants. Gallien and Wein (2005) designed a "smart" market for electronic trade in real time for industrial procurement with capacity constraints. 
Murphy et al. $(2000 ; 2009)$ proposed a smart market to allocate surface water on a channelized network. They found that a market cleared with a linear programming model with environmental constraints would encourage participants to obtain "beneficial trades," while reducing coordination problems and transaction costs. Raffensperger et al. (2009) developed a linear program to clear a market for ground water. They set up the market with a hydrogeologic simulation to estimate individual impact coefficients at different specific locations (control points) in the catchment. The impact coefficients were the constraint coefficients in the market-clearing optimization. Additionally, the authors noted that the smart market design would reduce transaction costs since participants need not search for trading partners, relevant information is widely available, and bargaining is simplified. Transaction costs are reduced at the expense of costs associated with initially setting up the market. Some costs which appear to be transaction costs are often already being paid even without trading, such as hydrology modeling, monitoring, and enforcement.

A smart market for impervious cover was proposed by Raffensperger and Cochrane (2010). They developed a market design for controlling runoff near environmentally sensitive areas. The authors noted that property owners would be encouraged to reduce impervious cover level and that governments would be able to improve the environment standards. In this case, property owners would face some transaction costs associated with selecting a set of options for land uses and management practices, calculating the associated costs and run-off factors, and then determining their bids. The government would also have to enforce the contracts by physically visiting owners' properties.

Prabodanie and Raffensperger (2007) and Prabodanie et al. (2010) developed a smart market for nitrate pollution. They addressed the issues of market clearing, transaction costs, and inter-temporal leaching effects over a long planning horizon. A central manager auctions licenses for discharging nitrates, while nitrates are limited by location. A linear program would 
allow trading within environmental limits in each time period. The transaction costs would be similar to those of the impervious cover market, where participants would have to determine which land uses and management practices were appropriate to their property, calculate the associated costs and run-off factors, and then determine the associated bids. Again, government agents would have to visit owners' properties to ensure that the owners made the changes they had agreed to do. This is similar to BushTender, the Victorian (Australia) government's program for native vegetation offsets (Plott et al. 2008).

This paper proposes a smart market for sediment discharge allowances. The market would encourage participants to manage their sediment discharges via BMPs and controlling technologies. This work is similar to recent work in smart markets for hydrological resources in overall structure and the non-point source nature of the discharge, but the physics, the nature of the rights, and consequently the market operation here are specific to sediment discharge. This paper substantially improves on existing market-based approaches for sediment control and non-point source. Because our market functions as a call market, in which potentially many participants have the opportunity to provide rich bid functions, and because the market is cleared in one action (possibly with preliminary rounds for price determination), we expect that this market will equilibrate quickly to a coordinated near firstbest outcome.

We discuss briefly proportional adjustment of initial allocations when grandfathering schemes are originally in place, as suggested by Raffensperger et al. (2009) and Raffensperger (2011), for scaling back with "constraint quota"; but also we point out ways for up-scaling. Scaling can allow auction solutions that are both feasible and revenue neutral. Distributional and fairness effects, and problems with property rights as a result of this scaling are outside the scope of this current paper, but are appropriate future work. 
Our market design for sediment discharge has the advantages of using all available hydrological information and accepting community input on the desired environmental standards. This approach explicitly avoids "the tragedy of the commons" (Hardin 1968) where the public eventually has higher costs due to environmental degradation and sedimentation, but these costs are not paid by those who create the problems. Our proposed method is computationally efficient and it calculates prices for sediment discharge based on auction bids and environmental standards. Our market design may be viewed as a type of cap and trade system (as with the previously mentioned smart markets for hydrological resources), but the set of caps is much richer than, say, for carbon trading.

The market could conceivably have non-convexities which may raise externalities, so it is important to characterize sediment load and transport coefficient models to identify possible non-convexities issues. While we recognize the potential importance of non-convexities, this paper does not focus on this issue, but rather uses a simpler physical characterization to develop the larger institutional design of the smart market.

\section{Market design}

This section describes our smart market design in detail. The first part covers the market operations, included a definition of the commodity traded, an explanation of the role of the market manager, a description of how the market manager calculates participant impacts, the bidding and market clearing processes, and enforcement. The second part gives the market model which clears the market, with an analysis of price relationships.

\section{SmartTDA market operations}

\section{What is traded}

The market requires a clear specification of what is being traded. We define tradable discharge allowance (TDAs) as a right to discharge one kilogram from a specific location 
(property), in a single catchment, where one or more aggregate sediment discharge caps must not be exceeded.

Market participation is compulsory, in the sense that the auction is the only legal means of obtaining the allowances, and the penalties for non-compliance should be charged at the market price at least. A participant may need more or fewer allowances, depending on their land use. Buyers would purchase allowances if they were planning to exceed their current sediment discharge rate due to development or other change in land use. Further, they would choose technologies and BMPs for controlling sediment discharge based on their opportunity costs, including the cost per TDA.

The difference between a participant's initial right and their desired rights will be resolved through the market. Figure 1 illustrates the main components of the smart market for sediment discharge. These components are described in detail in the next paragraphs.

\section{Role of the market manager}

Our market design requires a central manager to oversee market operations. This market manager could be an environmental agency. The manager specifies sediment limits in the catchment, accepts bids from market participants, clears the market with the optimization model, update and informs, and monitors and enforces the resulting agreements.

It is important to understand that participants would not trade bilaterally. Rather, all participants buy from and sell to a central market manager simultaneously, through a common pool.

\section{Control points and impact coefficients}

The proposed market is an auction to sell or buy TDAs to discharge sediment in ways which impact specific locations in the catchment. We will call these locations "control points". These control points could be the outlets of a catchment, a river mouth, or a channel. The market manager would set limits on the maximum sediment allowed to reach each control point. 
In addition to these limits, the manager must determine the sediment impact of each participant's existing and proposed actions. To calculate these limits, the manager can use erosion and sediment transport models, based on participants' land uses. We assume that the sediment simulated by an erosion model for a particular site passes through at least one control point. We recognize that many uncertain and unobservable factors affect estimates of impact coefficients from point and non-point sources, but we leave those considerations outside in this market design; we treat the coefficients from sources as certain in the market formulation. The transport models provide the impact coefficients, $F_{i k}$, the change in sediment received at control point $k$, as a result of a unit increase in discharge by participant $i$ at the participant's location. This coefficient is between 0 and 1, but often can be 1 in sediment load areas close to control points. We assume that sediment transport relationships are linear, although a convex non-linear function could be accommodated by adjusting the constant on the RHS of equation (4) below. In our case study, the catchment is small and we assume variations in the time required for the sediment to reach the control point from various properties are not significant over a given length of storm event.

The Contaminant Load Model (ARC CLM) and Groundwater Loading Effects of Agricultural Management Systems (GLEAMS) are currently used to evaluate impacts of development and control in rural and urban places in New Zealand with most applications focussing on water quality issues. Parshotam and Wadhwa (2007) applied GLEAMS and ARC CLM within the Central Waitemata Harbour to predict contaminant sources and sediment loss for different development and land use scenarios.

We used ARC CLM (ARC 2006) to predict sediment discharge from urban sites, and to simulate erosion control measures. ARC CLM estimates annual sediment load from different sources within a catchment based on the fraction of source area draining, source yield and load 
reduction factor for given management trains. Yields are estimated from available studies and empirical data.

For large scale predictions, we used GLEAMS (Knisel et al. 1992). GLEAMS is a continuous simulation model which uses steady-state equations for defining hydrological processes and soil erosion from non-point sources. The hydrological component uses a modification of the SCS curve number approach and the erosion model components estimates soil erosion based on a continuity mass expression (Foster et al. 1980; Tapia-Vargas et al. 2001). In GLEAMS, the catchment area is divided into a matrix of grid cells where non-point source erosion is predicted for each grid cell and is routed through the channel. Sediment yield is then predicted at control points in the catchment channel network. We assume the models would estimate sediment discharge with a reasonable degree of certainty and that participants who participate in the market would accept the model outcomes. Market participants who disagree with the predicted yields could have the option of paying for additional modeling from approved hydrology consultants, or for monitoring their sediment discharge.

Following calculation of the impact coefficients, the market manager has all the required information to clear the market, except for participants' bids.

\section{Bidding}

At the beginning of the auction, each participant has some known initial allowances. (Scaling of rights may be necessary to establish this initial position, but the details are discussed later.) Each participant may want to buy more rights, or sell existing rights. Market participants express their willingness to trade through their bids in a monotone increasing way.

Operation of the auction requires that all buyers and sellers are ready to trade at a given point in time. Sellers and buyers are informed in advance about the auction rules. To decrease transaction costs, auction participants could bid over the internet. The auction starts when all buyers and sellers are ready to trade at a given point in time. This auction could operate at 
intervals such as once a month, every four months, or once a year. This auction schedule will be important to participants, who may wish more frequent auctions for their own higher liquidity, or less frequent auctions for thicker markets. Raffensperger et al. (2009) and Prabodanie et al. (2010) noticed a similar issue with their proposed markets for nitrate. In any case, the auction schedule will depend heavily on specific conditions in the catchment and preferences of the participants. The combination of an initial allocation, an offer curve and a buy curve defines a demand curve representing the value each participant places on various levels of discharge rights that they could hold. This allows us to formulate the market-clearing auction as a "gross pool", as in many electricity markets. The gross pool ignores initial rights in the model, and uses that data in book-keeping separately. A "net pool" formulation could be developed, in which each participant provided an offer curve, to sell rights, and a separate bid curve, to buy more. But Montgomery (1972) noted that a market equilibrium may be achieved independently of the initial allocation, and independent of re-distributional effects, assuming sufficiently low transaction costs (Coase 1960; Stavins 1995).

The demand curves are expressed in steps of price and quantity pairs, for the right to discharge incremental quantities of sediments, thus providing a piecewise linear approximation of each participant's value function for discharge. Fundamentally the price and quantity pairs represent the value participants place on various land uses, control technologies and BMPs, and development projects on their properties.

The number of steps in each participant's value function would ideally be arbitrary, as participants should themselves be able to choose the form of their own bids. Some markets standardize these steps. For instance, Victoria gas and New Zealand electricity markets allow up to 10 steps for each participant. The TDA market could allow between 1 and 6 steps; the maximum number is mainly a problem of software design. 
To express bid quantities in terms of discharge units, the erosion model must be run to predict erosion for each property, under alternative land use options. If a participant proposes a change that increases (or decreases) erosion, and therefore changes sediment discharges from their property over the time period, this participant would have to buy more (or could sell some) discharge allowance through the auction. Discharges and impacting coefficients are estimated from point and non-point sources under certainty conditions via ARC CLM or GLEAMS, either by the auction manager, or by the participants via some sanctioned software. On market clearing, participants would then be deemed to have the discharge as calculated by the model, and would be obligated to fulfill the agreed land use changes and management practices. The auction manager can specify precautionary ratios developed from run-off distributions (as in Shortle and Horan 2008), or precautionary caps (as in Raffensperger and Cochrane 2010). The auction manager could develop a full stochastic program (as in the first author's $\mathrm{PhD}$ thesis, currently underway). Under any of those options, the market participants still can be held responsible only for their land uses and management practices, because discharges are inherently uncertain.

Some abatement technologies are indivisible; implying that the marginal abatement cost is discrete. If the auction were to choose which technology each participant should use, the optimization would have integer decision variables and would be a non-convex problem, resulting in prices that may not provide participants with appropriate incentives to implement the proposed solution. Consequently, we leave participants to adjust their (continuous) demand curves to achieve technology/land use combinations that are feasible for them. For instance, if a participant offering control through a sediment settling pond got a solution representing only half of the pond, the participant should offer a lower price in the next auction to get a feasible integer solution representing the whole pond. 
To assist participants in bidding, to give them some price discovery, the manager could operate a series of tentative rounds before the final binding auction. We assume participants have sufficient knowledge about their costs for land uses and management practices, but that data and the financial consequences of the auction outcomes are private to the participants. To set prices, the manager does not need to know each participant's true private cost information, but only their bids.

Because our system reduces transaction costs, trading should be more active than without our system. However, trading may still be thin because some transaction costs remain, and because few land owners need construction or land use change. Thin trading is not necessarily a problem as long as targets are satisfied, unless it is so thin that only one side of the market is represented, or the regulator wishes to reduce sediment load targets over time. So the manager may wish to encourage participant participation (Shortle and Horan 2001; Shortle and Horan 2008). Raffensperger and Cochrane (2010) noted that the implementation of a renewal system would incentivise participation. The manager could annul some or all rights at regular intervals, and require land owners to re-purchase the allowances. Sellers or buyers would need to enter the auction at any change of land use, technology change or major development.

\section{Market clearing with optimization}

At the close of bidding, the manager uses Model SmartTDA (below) to clear the market and to determine prices and allocations for each participant. Model SmartTDA calculates quantities and prices traded between different participants. The quantities come from the primal solution. Prices come from the dual solution to the model, and depend on the environmental impact (to the extent that these impacts are modeled as sediment loads), the participants' reservation prices represented by bids/offers (demand) and the environmental caps as constraints.

The auction balances net buyer demand against the constraint limits. With the optimization model, a market for tradable emission or discharge can work with multiple receptors and many 
dischargers. Because all participants trade through the market manager, bilateral (pair-wise) trades are not necessary. There may be no decomposition in terms of a sequence of bilateral trades in which parties wishing to increase discharge seek only to buy discharge permits, and parties willing to reduce discharge seek only to sell discharge permits. (There will be a solution if some party is prepared to act as market maker, simultaneously buying and selling permits while managing any imbalance with respect to constraint capacities. But that effectively makes that party responsible for finding and implementing the pool solution developed in this paper). The smart market significantly reduces transaction costs, combining the search for trading partners, price discovery, contracting, and regulatory approval all into one action.

Following solution of the model, the market manager immediately announces the final allocations and prices. The manager records the participants' new TDAs based on their initial allocations and their trades.

\section{Enforcement}

Auction rules would require that all participants abide by land uses and management practices for which their bids were accepted. Following market clearing, therefore, the market manager (or some other party) must enforce the agreed behaviors of the contract holders. Ideally, the auction manager would enforce the actual discharges and impacts. However, these discharges are uncertain, and the auction manager's selected discharge model may be incorrect. Hence, the auction is fundamentally about participants' land use and management practices. The auction manager can also monitor actual discharges and impacts. If the monitored sediment discharge proves to be less than the ARC CLM or GLEAMS model predictions, the auction manager could give the participant a discharge allowance which they could either use or sell.

The market system would reflect the costs of meeting environmental limits back onto the parties' activities putting pressure on those limits. From the market, prices will be calculated 
that signal resource scarcity. The system would incentivize improved management of sediment discharge and use of BMPs, especially near environmentally sensitive areas. Trade would lead to the lowest social cost, if participants bid truthfully and rationally, as would be expected under perfect competition. (For more details on setting prices, innovation and strategic decisions, see Laffont and Tirole (1996a; 1996b), Kwerel (1977) and Montero (2008). The goal of such a market would be to enable society to satisfy a range of desired environmental outcomes at minimum cost.)

\section{Model SmartTDA}

We next describe the market clearing model algebraically, with an analysis of the prices. The model is a gross pool model, in which all participants bid their full demand curve as though they were only buying. After solution of the model, net trades are calculated based on users' initial allowances. Users face marginal cost prices (rather than price as bid), based on dual variables from the model. Given the impact coefficients $F_{i k}$ from the numerical model, and the participants' submitted bids, the market manager can create the following market-clearing optimization model.

\section{Indices}

$i$

$$
=\text { participant, } i=1, \ldots, n \text {. }
$$

$k \quad=$ control points, $k=1, \ldots, K$.

$b \quad=$ demand curve step, $b=1, \ldots, B$.

\section{Parameters}

$C_{i}=\quad$ Initial discharge rights for participant $i(\mathrm{~kg})$.

$D_{i b}=$ Maximum amount that participant $i$ is willing to end up holding in step $b$ of its demand curve, at price $P_{i b}(\mathrm{~kg})$.

$F_{i k}=$ Impact coefficient, which is the marginal change in sediment discharged by participant $i$ received at control point $k$. ( $\mathrm{kg}$ in control point vs. $\mathrm{kg}$ discharged). 
$P_{i b}=\quad$ Step price per kg for discharging sediment from participant $i$ and demand curve step $b$. This is the maximum that participant is willing to pay for one more $\mathrm{kg}$ of sediment discharged $(\$ / \mathrm{kg})$, at that level, and also the minimum for which they would be prepared to discharge one less.

$S_{k}=\quad$ Maximum allowable sediment received at control point $\mathrm{k}(\mathrm{kg})$, from these discharges (ie. net of any other sediment load).

\section{Decision variables}

$g_{i}=\quad$ Total discharge rights for participant $i .(\mathrm{kg})$

$p_{i}=\quad$ Price to discharge for participant $i .(\$ / \mathrm{kg})$

$\lambda_{k}=\quad$ Price to discharge at the control point $k .(\$ / \mathrm{kg})$

$q_{i b}=$ Amount in kg discharged by participant $i$ and bid steps $b=1, \ldots, B .(\mathrm{kg})$

$\operatorname{qsell}_{i}\left(q b u y_{i}\right)=$ Amount in $\mathrm{kg}$ sold (bought) by participant $i .(\mathrm{kg})$

\section{The LP discharge/pricing model}

$\operatorname{Maximize} \sum_{i}^{n} \sum_{b}^{B} q_{i b} P_{i b}$

Subject to:

$0 \leq q_{i b} \leq D_{i b}$, for all participants $i$, and steps $b=1, \ldots, B$.

$g_{i}=\sum_{b}^{B} q_{i b}$, for all participants $i$

$: \gamma_{i b}, \beta_{i b}$

$\sum_{i}^{n} F_{i k} g_{i} \leq S_{k}$, for each control point $k=1, \ldots, K$

$: \lambda_{k}$

$g_{i}$ free

\section{Explanation}

1. Maximize total gains from trading sediment allocation. This type of objective is well accepted in the smart market literature (McCabe et al. 1991; Hogan et al. 1996; Murphy et al. 2000; Murphy et al. 2009; Raffensperger et al. 2009). The objective function does not measure the absolute welfare, but changes in the objective are the appropriate measure of 
changes in welfare (assuming the market is competitive enough that offer/bids reflect marginal costs). We recognize participants could try to bid strategically; but that issue is beyond the scope of our paper.

2. Participant $i$ will sell (buy) discharge rights up to their specified demand curve step, at the specified price. The shadow prices on this constraint are $\beta_{i b}$ and $\gamma_{i b}$, which play an important role in the pricing discussion below.

3. The total discharge by participant $i$ equals the sum of discharge bid steps $(\mathrm{kg})$. The shadow price $p_{i}$ on this constraint represents the price to be paid or received by participant $i$ for incremental discharge rights.

4. Total sediments are limited at each control point $k$. The shadow price $\lambda_{k}$ on this constraint is the price, representing the marginal gain to the economy from trade if the environmental constraint limit could be relaxed by one unit.

5. Buy and sell quantities must be non-negative, as must the offer/bid block variables. This non-negativity will limit the final allocation of rights, $g_{i}$. Imposing additional limits on $g_{i}$ would over-constrain the problem, creating degeneracy (where a constraint is binding, but has a price of 0) for redundant constraints which could compromise prices (Gal 1986).

The shadow price $p_{i}$ indicates the increase in total value to the rest of the system, if we give participant $i$ another $\mathrm{kg}$ allowance; $p_{i}$ will be non-positive at the optimum, meaning that total value will be reduced if we give participant $i$ another $\mathrm{kg}$. This is the price that the market manager should charge participant $i$ for the right to discharge an additional unit $(\mathrm{kg})$ of sediment from their property. As one might expect, analysis of the dual LP problem reveals that this price is determined by the impact such discharge is expected to have on the sediment received at control points $k=1, \ldots, K$, where sediment levels are binding. Because no other constraints are modelled in the sediment transport system, this discharge price may be expressed in the following simple form: 
$p_{i}=\sum_{k}^{K} F_{i k} \lambda_{k}, \quad$ for all participants $i . \quad: g_{i}$

The discharge permits are valued at price $p_{i}$, which reflects the costs imposed by the impact that discharge has on each control point. Effectively this means that each "discharge right" can be re-expressed as an equivalent bundle of "constraint rights", each constraint valued at its own shadow price $\lambda_{k}$. In general, this price will not match the demand price offered by of participant $i$, on any step of their discharge demand curve. From the dual, the lower bound of $q_{i b}$ in (2) is negative $\gamma_{i b} \leq 0$; however, we would express it in a canonical way to have $\gamma_{i b} \geq 0$ and so simplify the analysis of the shadow prices (about detail see e.g., Winston 1994). In general, we have:

$$
p_{i}=P_{i b}-\beta_{i b}+\gamma_{i b}, \quad \text { for all participants } i, \text { and steps } b=1, \ldots, B .
$$

If $0<q_{i b}<D_{i b}$, then the optimal discharge right allocation for participant $i$ lies somewhere in the middle of step $b$, and this makes $i$ "marginal". This means that neither the upper or lower bound of that demand curve step will be binding; so, by complementary slackness, $\gamma_{i b}=\beta_{i b}=0$. Equation (7) implies that $p_{i}=P_{i b}$, the offer/bid price offered for that demand curve step. Only a few marginal offer/bid steps will be in each market clearing solution, typically one for each binding control point limit, but they will set prices throughout the system. All other offer steps will be either "infra-marginal" or "supra-marginal".

Supra-marginal steps are those for which the demand price $P_{i b}$ exceeds the market clearing price $p_{i}$ at that location. All such steps will be cleared by the auction, because they each represent a use whose value exceeds the costs imposed on the rest of the system. This means they will have $q_{i b}=D_{i b}$, and by complementary slackness $\beta_{i b}>0$. But the lower step limit can 
not also be binding, so $\gamma_{i b}=0$. In other words $\beta_{i b}$ adjusts to match the difference between $P_{i b}$ and $p_{i}$, in accordance with equation (7).

Infra-marginal steps are those for which the demand price, $P_{i b}$ is lower than the market clearing price at that location, $p_{i}$. No such steps will be cleared by the auction, because they represent uses whose value is less than the costs imposed on the rest of the system. This means they will have $q_{i b}=0$, and by complementary slackness $\gamma_{i b}>0$. But the upper step limit can not also be binding, so $\beta_{i b}=0$. In other words $\gamma_{i b}$ adjusts to match the difference between $P_{i b}$ and $p_{i}$, in accordance with equation (7).

After clearing the model, the trades are adjusted for the initial allocation by a referential constraint as follows:

$g_{i}=q b u y_{i}-q s e l l_{i}+\alpha C_{i}, \quad$ for each participant $i . \quad: \varepsilon_{i}$

Because $q b u y_{i}$ and $q s e l l_{i}$ are unconstrained, they will not affect the solution, or prices. They are used only to determine buy/sell quantities and could be omitted from the LP clearing formulation.

In the market auction settlement, each participant $i$ should be charged (or paid, if the value is negative) $p_{i}\left(q b u y_{i}-q s e l l_{i}\right)$. These clearing prices indicate the economic costs for increasing sediment discharge by potential auction participants, and are useful for planning and policy purposes. In fact, the same prices would be produced by an optimisation model run by a central planner, using the same end-use value curves, to choose least-cost policies.

\section{Managing over-allocation and under-allocation}

If the catchment is over-allocated, the manager must have previously granted rights above the catchment's newly established limits. (Over or under allocation could arise from a difference between monitoring and simulations, but also from many other causes, including introduction 
of a new permit regime, changes to allowable limits, and growth toward saturation of previously non-binding constraints.) Normally, if a party (the manager in this case) has sold rights for a product that cannot be delivered, we would expect them to be liable to at least refund the purchase price, if not compensate the purchasers for any losses that may arise. One way of doing this would be for the market manager to be a participant, purchasing TDAs so as to bring the allocated rights down to the catchment's limits. Re-purchase prices may be very high, because participants, having already invested on the basis of allocated rights, will see high economic costs in downsizing. But these prices are appropriate because they represent real costs to society. Requiring the manager to manage constraints in this way incentivizes the manager to exercise appropriate care in allocating rights.

However, the normal rules of economics and commercial law may not apply to regulatory authorities, and the market manager may wish to adjust allocations while also maintaining revenue neutrality. If limits are scaled down, participant rights must also be adjusted downward somehow, and Raffensperger (2011) discusses a number of options to achieve revenue "sufficiency". A simple approach would be to make proportional adjustments to all discharge rights, thus multiplying $C_{i}$ by $\alpha$ in equation (8) $(0 \leq \alpha \leq 1)$, with $\alpha$ set so as not to overload the most critical control point. But this scaling is unnecessarily severe, if more than one receptor is involved, and nor does it revenue "neutrality". To achieve that goal, we must first decompose discharge rights for participant $i$ into a weighted bundle of notional "constraint impact rights", $C_{i k}$ :

$C_{i}=\sum_{k}^{K} F_{i k} C_{i}=\sum_{k}^{K} C_{i k}$, for all $i$

Scaling discharge rights implicitly scales constraint impact rights for each constraint by the same fraction, whether or not it is over-allocated. This is unlikely to be revenue neutral, because the market will generally clear with participants, in aggregate, having to implicitly 
buy back "constraint rights" which they had previously been allocated, but lost through the scaling process, just to maintain their status quo position. But, because equation (8) has no impact on the market solution, and only affects settlements after the market clears, the market manager has considerable flexibility as to how initial rights are treated in the settlement process. One can imagine various schemes that preserve revenue neutrality by re-distributing any profit/loss among participants. But to preserve revenue neutrality within the auction itself, we need to re-set the initial position of each participant by scaling the constraint right components, $C_{i k}$, for each constraint $k$ (up or down) to match the new constraint limit for $k$. That scaling need not be linear, so long as the total matches the new constraint limit. It could, for example, give older rights priority over newer ones, or purchased rights priority over inherited ones. But we will assume that the implicit rights associated with constraint $k$ are all scaled proportionately, by $\alpha_{k}$. If we let $C_{i}^{*}$ be the market-clearing discharge for participant $i$, the net payment required, after scaling initial constraint rights, $C_{i k}$, would be:

$r_{i}=\sum_{k}^{k} F_{i k}\left(C_{i}^{*}-\alpha_{k} C_{i}\right) \lambda_{k}$, for all $i$

This scaling ensures that all constraint limits are fully allocated at the beginning of the auction. So the amounts implicitly bought by the new owners will match those implicitly sold by the old owners, thus ensuring revenue neutrality. When the auction clears, some of the new constraint limits could be slack, in which case no money changes hands because the price is zero. But all those involved in binding constraints will make or receive some payment. Participants who decide to continue activities unchanged will need to maintain their discharge rights by making supplementary payments to restore the pre-scaled level of their rights with respect to any constraint for which rights had to be scaled down. But they would receive allowances for implicit rights held with respect to any constraint which had been underallocated (so rights could be scaled up), but now has a positive constraint price because it is 
fully allocated. To preserve feasibility, though, some participants must decide to reduce or adapt their activities, and they will receive payments for releasing rights for the tightened constraints, and most likely for other constraints too.

Participants may not think this ideal, but it is the best that can be done, in terms of preserving initial right allocation, while preserving revenue neutrality. They will not like having to pay more to maintain rights they have already bought, but this is inevitable if some rights have to be scaled back, and this proposal at least minimizes that requirement. They may also find the transactions difficult to understand, and hence accept, especially if the $F$ coefficients have a complex structure. That could be the case if, say, the market manager imposed a variety of constraints to deal with the differing pollution impacts of various usage types, at various locations, in the context of a groundwater model, such as that of Raffensperger et al (2009). In our case, though, the $F$ coefficients have a simple structure. Sediment from each source will pass down a series of channels to the ultimate sink, and the amount passing one receptor cannot rise, as we move downstream because channel erosion is not simulated. A participant may be affected by the tightening of limits at several control points, but those control points will lie on a path between the participant and the sink, and the participant's proportional interest will be greatest in the closest control points. All participants upstream of each control point where limits are tightened will implicitly have to trade between themselves, and with no-one else, to bring aggregate discharge within the new limit. Thus, for example, the payment required from a participant who opts not to change their activity would be expressed as a list of part-payments for maintaining their position with respect to sediment passing through each tightened control point between them and the sink. Participants who reduce their dispatch may see a mix of debits and allowances, but the structure of the transactions should still be fairly clear, greatly increasing the likelihood of acceptability. 
For example, suppose three participants, $A, B$ and $C$, want to trade. Each participant has an initial right to discharge $10 \mathrm{~kg}$. Each participant would buy extra discharge allowance for \$1 per kg above their existing allocation or would sell their existing allocations for $\$ 2$ per $\mathrm{kg}$. The marginal impact of a $1 \mathrm{~kg}$ discharge on sediment at control point 1 is: $F_{i l}=0.2$ and 1 for $A$ and $B$ respectively, and for control point 2: $F_{i 2}=0.1,0.8$ and 0.2 for $A, B$ and $C$ respectively. The limits on sediment at control points 1 and 2 are $9 \mathrm{~kg}$ each. As shown by point I on Figure 2, sediment discharges are initially over-allocated: $10 * 0.2+10 * 1=12 \mathrm{~kg}$ at control point 1 , and $10 * 0.1+10 * 0.8+10 * 0.2=11 \mathrm{~kg}$ at control point 2 , compared to the $9 \mathrm{~kg}$ limits. Final discharges are $45 \mathrm{~kg}$ for $A, 0 \mathrm{~kg}$ for $B$, and $22.25 \mathrm{~kg}$ for $C$, implying $9 \mathrm{~kg}$ of sediment at both control points 1 and 2, as at point $\mathrm{L}_{2}$ in Figure 2. Market clearing prices are $\$ 5$ and $\$ 10$ per $\mathrm{kg}$, at control points $1 \& 2$ respectively. Setting $\alpha_{1}=9 / 12=0.75$ and $\alpha_{2}=9 / 11=0.8181$ scales initial rights (in aggregate) also to $\mathrm{L}_{2}$. Total charges for $A$ are then $\$ 74.31$, since it has to implicitly pay $\$ 5 / \mathrm{kg}$ for an extra $0.2 *(45-0.75 * 10) \mathrm{kg}$ of sediment impact at control point 1 , and $\$ 10 / \mathrm{kg}$ for an extra $1.0 *(45-0.8181 * 10)$ of sediment impact at control point 2 . Similarly, $C$ has to pay $\$ 28.64$, while $B$ receives $\$ 102.95$, thus achieving revenue neutrality. By way of comparison, the regulator would have to pay $\$ 35$ if initial rights were not adjusted, and would receive $\$ 7.50$ if they were scaled down proportionately (by $25 \%$ ) to achieve feasibility with respect to constraint 1 , as at point $\mathrm{L}_{1}$ in Figure 2.

If the limit for control point 2 were to be increased to $15 \mathrm{~kg}$, though, that capacity would initially be under-allocated, not over-allocated. Under the same assumptions, the market clearing solution lies at $\mathrm{L}_{3}$ in Figure 2, with discharges of $45 \mathrm{~kg}$ for $A, 0 \mathrm{~kg}$ for $B$, and $52.5 \mathrm{~kg}$ for $C$. The market clearing prices at control points 1 and 2 are still $\$ 5$ and $\$ 10$ per $\mathrm{kg}$. Setting $\alpha_{1}=0.75$ and $\alpha_{2}=15 / 11=1.36$, scales the aggregate initial right allocation also to $\mathrm{L}_{3}$. Then $A$ pays $\$ 68.86, C$ pays $\$ 77.73$, and $B$ receives $\$ 146.59$, giving revenue neutrality. By way of 
comparison, the regulator would receive $\$ 25$ if initial rights were not adjusted, and $\$ 67.50$ if they were scaled down proportionately (again to $\mathrm{L}_{1}$ because constraint 1 is still critical).

\section{Market simulations and discussion}

\section{Example application: Auckland, New Zealand}

We discuss a hypothetical example applying the SmartTDA model using the GLEAMS and ARC CLM models, to a small catchment in Auckland, New Zealand. The relevant local government manager could be the Auckland Regional Council (ARC). We consider two stormwater manager units (SMU) representing a small subcatchment within the Swanson catchment in Auckland. Figure 3 illustrates the subcatchment layouts with the initial land use conditions. The number and size of specific properties within the SMU are assumed for this application, but exact values were not available for our study. We assume that all sediments are discharged to a stream with one control point. Every property is assumed to have one point of discharge and participants have initial rights explicitly. Table 1 summarizes the estimated sediment discharged (initial rights) from both SMUs and the land use. We assume 50\% impervious cover in urban areas, and use ARC CLM to calculate the resulting sediment discharge.

For our demonstration, suppose a few developers within these SMUs wish to discharge an extra amount of $330.130 \mathrm{~kg} / \mathrm{year}$ (participants 3, 15 and 19). If a discharge for the SMU (catchment) were not regulated, developers would not be pressured to control sediment discharge. However, if an upper limit of sediment discharge is set for a specific control point, the participants would be required to control discharges in the catchment. To control their discharge, participants can choose a best management practice (BMP) or erosion control. Participants can evaluate the effectiveness of the different BMPs and estimate these differences in sediment controls by using ARC CLM or GLEAMS. 


\section{Participants and trading requirements}

To minimize their own costs, the developers want to participate in the auction to buy discharge allowances. They evaluate available technologies to control sediment discharge according to their opportunity cost, determining their minimum (maximum) willingness' to accept (pay). Participants choose their bids based on the cost of BMPs and technologies to reduce sediment, as well as their profits associated with a given level of sediment discharge. Every participant has three options. We assume costs for each technology, and that the cost of technologies to control sediment discharge is different for each participant. Each participant has different characteristics and requirements.

We develop bids for 20 notional participants, participants 1-16 in the SMU1 subcatchment, and participants 17-20 in the SMU2 subcatchment. Table 2 summarizes these participants as well as their options. To retain initial sediment rights, participants should bid in their first tranche a price high enough to signal their maximum willingness to pay for keeping the initial conditions; otherwise, the market clearing model would view a low offer as the participants' willingness to trade the sediment rights. In this example, we assume prices are high enough in the first tranche for those who want to keep initial conditions and low for those who want to trade a proportion of their total sediment rights. We assume that every participant's discharge has a one-to-one effect on the control point, so $F_{i}=1$ for all participants $i=1, \ldots, 20$. Some participants such as participant 3 (described below) plan construction, and therefore could use the ARC CLM model to plan their bids. Other participants such as participants 3 and 15 (described below) plan land use changes, and could use the GLEAMS model to plan their bids. We also give an example of urban land owned by the environmental authority, as participant 20.

Participant 1 has 2.35 hectares with native forest to be discharging $603 \mathrm{~kg} / \mathrm{year}$. Having evaluated several practices and opportunity costs, this participant wishes to implement a 
different land use under BMPs which implies 30\% sediment control. The participant could implement the BMPs sequentially in 1.4 ha, 0.47 ha and 0.47 ha of land, and reduce $108 \mathrm{~kg}$, $36 \mathrm{~kg}$ and $36 \mathrm{~kg}$ of sediment respectively. The technology control costs are $\$ 1,000, \$ 1,000$ and $\$ 1,100$ respectively.

Participant 3 has 16.1 hectares with pine plantations to be discharging 3,331 kg/year, and wants to harvest 6 hectares to discharge an additional 265,412 $\mathrm{kg} /$ year. Having evaluated several practices and opportunity costs, the participant wishes to implement BMPs to control discharge with the following options:

- 4 hectares with BMPs to control $140,432 \mathrm{~kg}$ of sediment (80\% control) costing $\$ 80,000$, implying \$0.57 per kg;

- 2 hectares with BMPS to control an additional $70,216 \mathrm{~kg}$ of sediment ( $80 \%$ control) costing an additional $\$ 178.000$, implying $\$ 2.54$ per $\mathrm{kg}$.

The participant demands allowances in the first step $265,412 \mathrm{~kg} /$ year for $\$ 0.57$ per $\mathrm{kg}$ because a greater price would incentivise participant to use BMPs. If the participant faces a price between $\$ 0.57$ and $\$ 2.54$, the participant could implement the first BMPs option and buy the uncontrolled difference of $124,980 \mathrm{~kg}$. If the price were between $\$ 2.54$ and $\$ 14$, the participant would use the two options of BMPs for the entire harvest plan and buy $54.764 \mathrm{~kg}$. The price of $\$ 14$ per $\mathrm{kg}$ is the maximum willingness to buy sediment allowances given that technologies do not control $100 \%$ the total sediments discharge with the new land use.

Participant 15 has 1.45 hectares with native forest and is discharging $372 \mathrm{~kg} /$ year. The participant wants to develop $4,251 \mathrm{~m}^{2}$. The project will last one year and would discharge $63.772 \mathrm{~kg} /$ year. The participant could implement BMPs or technologies to control discharge from the property starting with a silt fence and wet pond to reduce sediment discharge. With these technologies and opportunity costs, the participant could choose the following options:

- a silt fence to control 31,886 kg of sediment, costing $\$ 20,000$, implying $\$ 0.63$ per kg; 
- a wet pond to control an additional $12,754 \mathrm{~kg}$ of sediment, costing an additional $\$ 60,000$, implying $\$ 4.70$ per kg;

The participant must participate in the auction because $13,393 \mathrm{~kg}$ would not be controlled even if all BMPs were implemented. The participant has a willingness to pay up to $\$ 15$ per $\mathrm{kg}$ for the uncontrolled amount of allowances. Thus, we shall assume that the participant will demand in the first step $63,772 \mathrm{~kg} /$ year for $\$ 0.63$ per $\mathrm{kg}$ because a greater price would incentivise participant to install the first technology. If the participant faces a price between $\$ 0.63$ and $\$ 4.7$, the participant could install the first technology and buy the uncontrolled difference of $31,886 \mathrm{~kg}$ at $\$ 4.7$ per $\mathrm{kg}$. If the price were between $\$ 4.7$ and $\$ 15$, the participant would install technologies to control sediment and buy the uncontrolled difference of 19,132 $\mathrm{kg}$ up to $\$ 15$ per $\mathrm{kg}$.

Participant 20 is an urban property, represented by the council. Assuming 50\% impervious cover, ARC CLM estimates the sediment discharged as $80,004 \mathrm{~kg} /$ year. To control discharge, the council has the following options.

- a storm-filter, to reduce $60,003 \mathrm{~kg}$, costing $\$ 500,000$, implying $\$ 8.33$ per $\mathrm{kg}$;

- a wet extended pond, to reduce a further $8,000 \mathrm{~kg}$, costing a further $\$ 150,000$, implying $\$ 18.75$ per $\mathrm{kg}$;

- a wet pond with flocculation, to reduce a further $3,600 \mathrm{~kg}$, costing a further $\$ 100,000$, implying $\$ 27.78$ per kg.

The council wishes to sell the sediment controlled in the market, in three tranches at the minimum prices of $\$ 8.33, \$ 18.75$ and $\$ 27.78$ per $\mathrm{kg}$ respectively.

\section{Case 1: neither under nor over-allocation. Total discharge rights equal the limit}

In this case, we assume that the manager sets a total discharge limit of $251,692 \mathrm{~kg} / \mathrm{year}$. The catchment is neither under-allocated nor over-allocated. Because the catchment is neither under nor over-allocated, we might expect that no trade will occur. However, participants have 
different opportunity costs, so in fact trade will happen. Table 3 summarizes the market outcome. The trades correspond to the amount bought (sold) of allowances from the manager and the positive (negative) sign of "net payment" means that the manager receives (pays) money. Similar notation will be used in the next summary tables for transactions in Case 2 and 3. The resulting trades were $74,803 \mathrm{~kg}$ to sellers and $74,803 \mathrm{~kg}$ to buyers. The clearing price in the market was $\$ 7.48$ per $\mathrm{kg}$. The manager would receive nothing, because the catchment was fully allocated initially. For instance, participant 3 bought $54,764 \mathrm{~kg}$ and paid $\$ 409,635$; participant 15 bought $19,132 \mathrm{~kg}$, and paid $\$ 143,107$, using both technologies to control sediment; and, participants 1 and 20 do not trade.

\section{Case 2: under-allocation. Total discharge rights are below limits}

In this case, the manager sets an upper limit for the catchment at $300,000 \mathrm{~kg} / \mathrm{year}$, which is above the existing total discharge rights. The catchment is now under-allocated. In this case, the clearing price in the market was $\$ 4.7$ per $\mathrm{kg}$, and the total quantities traded of allowances were $53,480 \mathrm{~kg}$ to sellers and $101,788 \mathrm{~kg}$ to buyers. The manager would receive a net $\$ 227,047$, because the manager participates as a net seller of excess discharge allowances (see last column in Table 4). For instance, participant 3 could buy 54,764 kg, the same quantity as in Case 1, but only would pay $\$ 257,391$, much less than in Case 1. Participant 15 could buy $45,171 \mathrm{~kg}$ (much more than Case 1), would use only one technology, and would pay $\$ 212,307$. Participants 1 and 20 do not trade. However, if the regulator wanted keep revenue neutrality, up-scaling could be done by setting $\alpha=1.19$. Table 4 summarizes the market outcomes. In this case, participants would receive an allowance. Total trade quantities traded after up-scaling would be $101,077 \mathrm{~kg}$ to seller and 101,077 $\mathrm{kg}$ to buyers. For instance, participant 3 would now pay $\$ 254,386$ compared to $\$ 257,391$ without the scaling which is like receiving an allowance of approx. $\$ 3,000$ from the up-scaling. Participant 15 would now pay $\$ 211,972$ which is 
approx. $\$ 500$ less than without up-scaling. Even though participants 1 and 20 do not trade, they also receive an allowance for the up-scaling of $\$ 544$ and $\$ 72,170$ respectively.

\section{Case 3: over-allocation. Total discharge rights exceed limits}

In this case, the manager sets a discharge limit of $150,000 \mathrm{~kg} / \mathrm{year}$ which is significantly lower than the original discharge limit of $251,692 \mathrm{~kg} / \mathrm{year}$ presented in Case 1. The manager observes that the current allocation is above the new limit of the catchment. Consequently, before the auction, the manager informs participants that the catchment condition is overallocated. To obtain an allocation that satisfies the control point constraint, the manager can adjust every participant's initial right by down-scaling using an $\alpha=0.59$. All participants lose some rights to discharge, without compensation. We note that this may be politically difficult (as mentioned earlier, government could choose to set a higher $\alpha$, in which case the manager would be a net buyer of discharge allowances). Then the manager runs the model again, determines prices and quantities, and pays or charges each participant. Table 5 summarizes the market outcomes. The clearing price in the market is $\$ 14.00$ per $\mathrm{kg}$, and total quantities traded were $71,884 \mathrm{~kg}$ to sellers and $71,884 \mathrm{~kg}$ to buyers. The manager would receive a net income of effectively $\$ 0$ (or $\$ 3$ due to rounding errors). All participants traded in this example. However, if initial rights had not been down-scaled, the regulator would end up paying $\$ 1,423,688$ after clearing the market (see last column in Table 5). This column was included in Table 5 to show the payment (receive) to/from each participant and the final payment from the regulator ($\$ 1,423,688)$.

Of particular interest are the participants 1, 3, 15, 16 and 20. Participant 1 would shift payment conditions if manager scales initial rights. Without scaling the manager would pay participant $1 \$ 1,512$ for reaching the wanted catchment condition; with scaling participant 1 would end up buying sediment allowances for $\$ 1,899$, but would achieve their original discharging right level. Participant 3 would harvest forest and would have to pay $\$ 636,064$ to 
buy sediment allowances. However, if they replanted forest the following year and sold sediment allowances, they could gain back some or all of these expenses. Participant 15 would buy $19,282 \mathrm{~kg}$ and would receive a debt of $\$ 2,100$ (approx) requiring a final payment from $\$ 267,848$ (without scaling) to $\$ 269,952$. To move back up to its original allocation, participant 16 would have to buy back an amount equivalent to the quantity adjusted downwards by the manager. On the other hand, participant 20 would sell discharge allowances and this money would pay for installing technologies to control discharge; however, the final payment would be reduced due to the debt for scaling receiving only $\$ 387,502$ compared to a value of $\$ 840,042$ without scaling.

\section{Conclusion}

A SmartTDA market to allocate sediment rights efficiently assigns allowances among participants, as the decision may be made more quickly and transparently. Further, the market will allow society to reduce its impact on the catchment at much lower cost, by enabling trade. Additionally, the market would allow down and up-scaling to keep the regulator revenue neutral.

Participants would face a market-price equilibrium which would incentivise better management to control sediment discharge in the catchment. The use of dual price $p_{i}$ enables the representation of valuated impacts at control points. The dual price $\lambda_{k}$ corresponds to the improvement in total welfare or trading value if the regulator gives another unit of receiving sediment at control point $k$. This value would encourage BMPs which would allow controlling sediment discharge, especially at environmentally sensitive areas.

The market design is based on erosion models which estimate impacts in routed systems. These may give poor impact estimates in some storm scenarios and catchment. Consequently, the models require substantial validation and testing to ensure the market's reliability. 
The proposed market design does not take into account the inter-temporal effects from the sediment movement along control points. Our illustration for the proposed market considered only instantaneous impacts into receptor control points and thus is only suited for a small catchments (388 ha approx). This effect on prices and allocations must be evaluated carefully, because effects beyond the planning horizon may distort clearing prices, allowing for instance, free riding participants. An improved version of this design could incorporate inter-temporal effects in the market.

Other limitations are the rainfall stochasticity, which affects sediment discharges from each property, and stochastic process in sediment transport, which affects impacting coefficients. These effects should be evaluated by the market manager and could also be incorporated in the market design. Possible problems with dimensionality and non-convexity should be studied in this case. We plan to study the risk implications for participants and the market manager, longer term impacts, and prices under stochasticity.

\section{Acknowledgments}

This work was supported by Auckland Regional Council. We thank NIWA (Hamilton) for running GLEAMS and providing simulation results for the catchment, and Dr. Shane Dye from the department of management, University of Canterbury, New Zealand, for his comments and suggestions in the document.

\section{Bibliography}

ARC (2006). "Contaminant load model." Auckland Regional Council, Auckland, New Zealand.

Coase, R. H. (1960). "The problem of social cost." J. Law Econ., 3, 1-44, doi:10.1086/466560.

Colby, B. G. (2000). "Cap-and-trade policy challenges: A tale of three markets." Land Econ., 76(4), 638-658, doi: 610.2307/3146957. 
Cronshaw, M. B., and Kruse, J. B. (1996). "Regulated firms in pollution permit markets with banking." J. Regul. Econ., 9(2), 179-189, doi: 110.1007/BF00240369.

Ermoliev, Y., Michalevich, M., and Nentjes, A. (2000). "Markets for tradeable emission and ambient permits: A dynamic approach." Environ. Resource Econ., 15(1), 39-56, doi: 10.1023/A:1008369611378.

Foster, G. R., Lane, L. J., Nowlin, J. D., Laffen, J. M., and Young, R. A. (1980). "A model to estimate the sediment yield from field-sized areas: Development of model." CREAMS: A field scale model for chemicals, runoff and erosion from agricultural management systems, USDASEA, 36-64.

Gal, T. (1986). "Shadow prices and sensitivity analysis in linear programming under degeneracy." OR Spektrum, 8, 59-71, doi: 10.1007/BF01719736.

Gallien, J., and Wein, L. M. (2005). "A smart market for industrial procurement with capacity constraints." Manag. Sci., 51(1), 79-91, doi: 10.1287/mnsc.1040.0230.

Garrick, D., Siebentritt, M. A., Aylward, B., Bauer, C. J., and Purkey, A. (2009). "Water markets and freshwater ecosystem services: Policy reform and implementation in the Columbia and Murray-Darling basins." Ecol. Econ., 69(2), 366-379, doi: 310.1016/j.ecolecon.2009.1008.1004.

Hardin, G. (1968). "The tragedy of the commons." Science, 162(3859), 1243-1248, doi: 1210.1126/science.1162.3859.1243.

Hill, E., Pugh, S., and Mullen, J. (2007). "Use of the hedonic method to estimate lake sedimentation impacts on property values in Mountain Park and Roswell, GA." Proc., Annual Meeting, Agricultural and Applied Economics Association, Portland, Oregon, 21.

Hogan, W. W., Read, E. G., and Ring, B. J. (1996). "Using mathematical programming for electricity spot pricing." Int. Trans. Oper. Res., 3(3-4), 209-221, doi: 210.1111/j.14753995.1996.tb00048.x. 
Knisel, W. G., Davis, F. M., and Leonard, R. A. (1992). "GLEAMS. User manual." Agricultural Research Service, U.S.D.A., ed., Southeast Watershed Research Laboratory, Tifton, GA.

Kwerel, E. (1977). "To tell the truth: Imperfect information and optimal pollution control." Rev. Econ. Stud., 44(3), 595-601.

Laffont, J. J., and Tirole, J. (1996a). "Pollution permits and compliance strategies." J. Public Econ., 62(1-2), 85-125, doi: 110.1016/0047-2727(1096)01575-01577.

Laffont, J. J., and Tirole, J. (1996b). "Pollution permits and environmental innovation." J. Public Econ., 62(1-2), 127-140, doi: 110.1016/0047-2727(1096)01576-01579.

McCabe, K. A., Rassenti, S. J., and Smith, V. L. (1989). "Designing smart computer-assisted markets." J. Polit. Econ., 5, 259-283, doi:210.1016/0176-2680(1089)90049-90049.

McCabe, K. A., Rassenti, S. J., and Smith, V. L. (1991). "Smart computer-assisted markets." Science, 254(5031), 534-538, doi: 510.1126/science.1254.5031.1534.

McCann, L., Colby, B., Easter, K. W., Kasterine, A., and Kuperan, K. V. (2005). "Transaction cost measurement for evaluating environmental policies." Ecol. Econ., 52(4), 527-542, doi: 510.1016/j.ecolecon.2004.1008.1002.

Montero, J. P. (2008). "A simple auction mechanism for the optimal allocation of the commons." Am. Econ. Rev., 98(1), 496-518, doi: 410.1257/aer.1298.1251.1496.

Montgomery, W. D. (1972). "Markets in licenses and efficient pollution control programs." J. Econ. Theor., 5(3), 395-418, doi: 310.1016/0022-0531(1072)90049-X.

Murphy, J. J., Dinar, A., Howitt, R. E., Rassenti, S. J., and Smith, V. L. (2000). "The design of "smart" water market institutions using laboratory experiments." Environ. Resource Econ., 17(4), 375-394, doi: 310.1023/A:1026598014870. 
Murphy, J. J., Dinar, A., Howitt, R. E., Rassenti, S. J., Smith, V. L., and Weinberg, M. (2009). "The design of water markets when instream flows have value." J. Environ. Manage., 90(2), 1089-1096, doi: 1010.1016/j.jenvman.2008.1004.1001.

Netusil, N. R., and Braden, J. B. (2001). "Transaction costs and sequential bargaining in transferable discharge permit markets." J. Environ. Manage., 61(3), 253-262, doi: 210.1006/jema.2000.0407

Pappas, E. A., Smith, D. R., Huang, C., Shuster, W. D., and Bonta, J. V. (2008). "Impervious surface impacts to runoff and sediment discharge under laboratory rainfall simulation." Catena, 72(1), 146-152, doi: 110.1016/j.catena.2007.1005.1001.

Parshotam, A., and Wadhwa, S. (2007). "Central Waitemata Harbour contaminant study. GLEAMS model structure, setup and input data requirement." Technical Report, National Institute of Water \& Atmospheric Research Lta., Auckland, 19.

Plott, C. R., Nemes, V., and Stoneham, G. (2008). "Electronic bushbroker exchange: Designing a combinatorial double auction for native vegetation offsets." Natinal MBI pilot program Rd2, Victorian Department of Sustainability and Environment, Melbourne.

Prabodanie, R., and Raffensperger, J. (2007). "Cleaning the water: A smart market for nitrates." Proc., MODSIM Conference, Christchurch, New Zealand, 2333-2339.

Prabodanie, R., Raffensperger, J., and Milke, M. (2010). "A pollution offset system for trading non-point source water pollution permits." Environ. Resource Econ., 45(4), 499-515, doi: 410.1007/s10640-10009-19325-10641.

Raffensperger, J., and Cochrane, T. (2010). "A smart market for impervious cover." Water Resour. Manag., 24(12), 3065-3083, doi: 3010.1007/s11269-11010-19595-y.

Raffensperger, J., Milke, M., and Read, E. G. (2009). "A deterministic smart market model for ground water." Oper. Res., 57(6), 1333-1346, doi: 1310.1287/opre.1090.0730. 
Raffensperger, J. F. (2011). "Matching users' rights to available ground water." Ecol. Econ. , 70(6), 1041-1040, doi: 1010.1016/j.ecolecon.2011.1001.1015.

Ribaudo, M. O., Horan, R. D., and Smith, M. E. (1999). "Economics of water quality protection from non-point sources: theory and practice." Agricultural Economics Report 728, U.S.D.A., Economic Research Service, Washington, DC, 106.

Shortle, J. S., and Horan, R. D. (2001). "The economics of non-point pollution control." J. Econ. Surv., 15(3), 255-289, doi: 210.1111/1467-6419.00140.

Shortle, J. S., and Horan, R. D. (2008). "The economics of water quality trading." Int. Rev. Environ. Resour. Econ., 2(2), 101-133, doi: 110.1561/1101.00000014.

Stavins, R. N. (1995). "Transaction cost and tradable permits." J. Environ. Econ. Manag., 29(2), 133-148, doi: 110.1006/jeem.1995.1036.

Stavins, R. N. (2004). "Environmental economics." Discussion Paper 04-54, Resources for the future, Washington, 19.

Strappazzon, L., Ha, A., Eigenraam, M., Duke, C., and Stoneham, G. (2003). "Efficiency of alternative property right allocations when farmers produce multiple environmental goods under the condition of economies of scope." Aust. J. Agr. Resource Econ., 47(1), 1-27, doi: $10.1111 / 1467-8489.00201$.

Tang, Z., Engel, B. A., Pijanowski, B. C., and Lim, K. J. (2005). "Forecasting land use change and its environmental impact at a watershed scale." J. Environ. Manag., 76(1), 35-45, doi: 10.1016/j.jenvman.2005.1001.1000.

Tapia-Vargas, M., Tiscareño-López, M., Stone, J. J., Oropeza-Mota, J. L., and VelázquezValle, M. (2001). "Tillage system effects on runoff and sediment yield in hillslope agriculture." Field Crop Res., 69(2), 173-182, doi: 110.1016/S0378-4290(1000)00139-00138. Tietenberg, T. H. (2006). "Environmental and natural resources economics." Pearson/Addison Wesley. 
Tinbergen, J. (1956). "Economic policy: Principles and design." North-Holland Publishing Company, Amsterdam.

Tisdell, J. (2007). "Bringing biophysical models into the economic laboratory: An experimental analysis of sediment trading in Australia." Ecol. Econ., 60(3), 584-595, doi: 510.1016/j.ecolecon.2005.1012.1018.

Westra, J. V., Zimmerman, J. K. H., and Vondracek, B. (2005). "Bioeconomic analysis of selected conservation practices on soil erosion and freshwater fisheries." J. Am. Water Resour. Assoc., 41(2), 309-322, doi: 310.1111/j.1752-1688.2005.tb03737.x.

Winston (1994). "Operations research: Applications and algorithms." Duxbury Press, Belmont, California.

Woodward, R. T., and Kaiser, R. A. (2002). "Market structures for U.S. water quality trading." Rev. Agr. Econ., 24(2), 366-383, doi: 310.1111/1467-9353.00025. 
Figure 1 Smart market components; P1, P2, P3 and P4 are participants who are located at different places in the catchment.

Figure 2 Impacting initial conditions and maximum capacity at control point. $\mathrm{I}_{,} \mathrm{L}_{1}$ and $\mathrm{L}_{2}$ are total sediment, and limits. Arrows represent the scaling conditions.

Figure 3 Sub-catchment schematic layout of the channel network, properties, and initial land uses for the example applications. Blue and black arrows represent channels and sediment directions respectively, and the black circle corresponds to the control point.

Table 1 Different land use, number of participants and sediment discharged from SMU1 and SMU2 stormwater management units in Auckland. Sediments discharged are calculated by ARC CLM for urban areas and GLEAMS for change in rural land use. We assumed twenty participants.

\begin{tabular}{lrrr}
\hline \multicolumn{1}{c}{ Land use } & Area, ha & $\begin{array}{c}\text { Sediment } \\
\text { discharge, kg/year }\end{array}$ & $\begin{array}{c}\text { Number of } \\
\text { participants }\end{array}$ \\
\hline SMU1 & & & \\
Pine mature trees & 16.1 & 3,331 & 1 \\
Native forest & 28.45 & 4,641 & 4 \\
Pasture/grassland & 129.6 & 144,450 & 10 \\
Urban & 28.2 & 13,376 & 1 \\
SMU2 & & & \\
Native forest & 0.73 & 36.7 & 2 \\
Pasture/grassland & 16.8 & 5,853 & 1 \\
Urban & 168.6 & 80,004 & 1 \\
Total & 388.48 & 251.692 & 20 \\
\hline
\end{tabular}

Table 2 Participants' initial discharge allowance, required discharge, quantity controlled, and the opportunity cost.

\begin{tabular}{ccccccccc}
\hline \multirow{2}{*}{ Participant } & $\begin{array}{c}\text { Initial } \\
\text { discharge } \\
\text { allowance, } \\
\mathrm{kg}\end{array}$ & $\begin{array}{c}\text { Required } \\
\text { discharge, } \mathrm{kg}\end{array}$ & \multicolumn{2}{c}{ Option 1 Control } & Option 2 Control & \multicolumn{2}{c}{ Option 3 Control } \\
\cline { 5 - 9 } & & $\mathrm{Kg}$ & $\$ / \mathrm{kg}$ & $\mathrm{Kg}$ & $\$ / \mathrm{kg}$ & $\mathrm{Kg}$ & $\$ / \mathrm{kg}$ \\
\hline
\end{tabular}




\begin{tabular}{lrrrrrrrr}
\hline 1 & 603 & 0 & 108 & 9.26 & 36 & 27.78 & 36 & 30.56 \\
2 & 603 & 0 & 85 & 12.00 & 24 & 38.00 & 12 & 66.00 \\
3 & 3,331 & 265,412 & 265,412 & 0.57 & 124,980 & 2.54 & 54,764 & 14.00 \\
4 & 3,063 & 0 & 536 & 3.73 & 153 & 9.79 & 77 & 19.59 \\
5 & 14,445 & 0 & 4,886 & 1.02 & 3,309 & 1.54 & 882 & 3.40 \\
6 & 14,445 & 0 & 12,654 & 3.16 & & & & \\
7 & 14,445 & 0 & 1,612 & 2.39 & 4,533 & 4.41 & 1,813 & 11.03 \\
8 & 14,445 & 0 & 4,533 & 6.62 & 4,533 & 6.62 & 2,684 & 11.18 \\
9 & 14,445 & 0 & 4,533 & 8.82 & 4,533 & 8.82 & 2,684 & 14.91 \\
10 & 14,445 & 0 & 2,341 & 8.54 & 4,533 & 11.03 & 870 & 22.98 \\
11 & 14,445 & 0 & 3,632 & 5.52 & 3,632 & 8.27 & 3,632 & 11.03 \\
12 & 14,445 & 0 & 4,533 & 4.41 & 4,533 & 6.62 & 907 & 11.03 \\
13 & 14,445 & 0 & 4,533 & 3.31 & 4,533 & 4.41 & 2,674 & 7.48 \\
14 & 14,445 & 0 & 11,469 & 3.49 & & & & \\
15 & 372 & 63,772 & 63,772 & 0.63 & 31,886 & 4.70 & 19,132 & 15 \\
16 & 13,376 & 0 & 8,427 & 15.00 & 1,484 & 20.00 & 1,039 & 25.00 \\
17 & 34 & 0 & 10 & 19.74 & & & & \\
18 & 5,853 & 0 & 3,476 & 5.75 & 1,392 & 14.37 & 981 & 15.29 \\
19 & 2.7 & 946 & 946 & 5.59 & 567 & 17.63 & 340 & 39.17 \\
20 & 80,004 & 0 & 60,003 & 8.33 & 8,000 & 18.75 & 3,600 & 27.78 \\
\hline Total & 251,692 & 330,130 & & & & & & \\
\hline
\end{tabular}

Table 3 Transactions for Case 1 where the catchment is neither under or over-allocated.

\begin{tabular}{lrrrrr}
\hline Participant & $\begin{array}{c}\text { Initial } \\
\text { discharge } \\
\text { allowance, } \mathrm{kg}\end{array}$ & $\begin{array}{c}\text { Allowance } \\
\text { sold, kg }\end{array}$ & $\begin{array}{c}\text { Allowance } \\
\text { bought, kg }\end{array}$ & $\begin{array}{c}\text { Final } \\
\text { discharge, kg }\end{array}$ & $\begin{array}{c}\text { Net payment, } \\
\$\end{array}$ \\
\hline 1 & 603 & 0 & 0 & 603 & $\$ 0$ \\
2 & 603 & 0 & 0 & 603 & $\$ 0$ \\
3 & 3,331 & 54,764 & 0 & 58,095 & $\$ 409,635$ \\
4 & 3,063 & 0 & 536 & 2,527 & $-\$ 4,009$ \\
5 & 14,445 & 0 & 9,077 & 5,368 & $-\$ 67,896$ \\
6 & 14,445 & 0 & 12,654 & 1,791 & $-\$ 94,652$ \\
7 & 14,445 & 0 & 6,145 & 8,300 & $-\$ 45,965$ \\
8 & 14,445 & 0 & 9,066 & 5,379 & $-\$ 67,814$ \\
9 & 14,445 & 0 & 0 & 14,445 & $\$ 0$ \\
10 & 14,445 & 0 & 0 & 14,445 & $\$ 0$ \\
11 & 14,445 & 0 & 3,632 & 10,813 & $-\$ 27,167$ \\
12 & 14,445 & 0 & 9,066 & 5,379 & $-\$ 67,814$ \\
13 & 14,445 & 0 & 9,682 & 4,763 & $-\$ 72,419$ \\
14 & 14,445 & 0 & 11,469 & 2,976 & $-\$ 85,788$ \\
15 & 372 & 19,132 & 0 & 19,504 & $\$ 143,107$ \\
16 & 13,376 & 0 & 0 & 13,376 & $\$ 0$ \\
17 & 34 & 0 & 0 & 34 & $\$ 0$ \\
18 & 5,853 & 0 & 3,476 & 2,377 & $-\$ 26,000$ \\
19 & 2.7 & 907 & 0 & 910 & $\$ 6,784$ \\
20 & 80,004 & 0 & 0 & 80,004 & $\$ 0$ \\
\hline Total & 251,692 & 74,803 & 74,803 & 251,692 & 0 \\
\hline & & & & & \\
\hline
\end{tabular}


Table 4 Transactions for Case 2 where the catchment is initially under-allocated and initial allowances are up-scaled by $\alpha=1.19$.

\begin{tabular}{lrrrrrrr}
\hline Participant & $\begin{array}{c}\text { Initial } \\
\text { discharge } \\
\text { allowance, } \\
\mathrm{kg}\end{array}$ & $\begin{array}{c}\text { Scaled } \\
\text { allowance, } \\
\mathrm{kg}\end{array}$ & $\begin{array}{c}\text { Allowance } \\
\text { sold, kg }\end{array}$ & $\begin{array}{c}\text { Allowance } \\
\text { bought, kg }\end{array}$ & $\begin{array}{c}\text { Final } \\
\text { discharge, } \\
\mathrm{kg}\end{array}$ & $\begin{array}{c}\text { Net } \\
\text { payment } \\
\text { with } \\
\text { scaling, } \$\end{array}$ & $\begin{array}{c}\text { Net } \\
\text { payment } \\
\text { without } \\
\text { scaling, } \$\end{array}$ \\
\hline 1 & 603 & 718.7 & 0 & 115.7 & 603 & $-\$ 544$ & 0 \\
2 & 603 & 718.7 & 0 & 115.7 & 603 & $-\$ 544$ & 0 \\
3 & 3,331 & $3,970.3$ & $54,124.7$ & 0 & 58,095 & $\$ 254,386$ & $\$ 257,391$ \\
4 & 3,063 & $3,650.9$ & 0 & $1,123.9$ & 2,527 & $-\$ 5,282$ & $-\$ 2,519$ \\
5 & 14,445 & $17,217.5$ & 0 & $11,849.5$ & 5,368 & $-\$ 55,693$ & $-\$ 42,662$ \\
6 & 14,445 & $17,217.5$ & 0 & $15,426.5$ & 1,791 & $-\$ 72,504$ & $-\$ 59,474$ \\
7 & 14,445 & $17,217.5$ & 0 & $8,917.5$ & 8,300 & $-\$ 41,912$ & $-\$ 28,882$ \\
8 & 14,445 & $17,217.5$ & 0 & $2,772.5$ & 14,445 & $-\$ 13,031$ & 0 \\
9 & 14,445 & $17,217.5$ & 0 & $2,772.5$ & 14,445 & $-\$ 13,031$ & 0 \\
10 & 14,445 & $17,217.5$ & 0 & $2,772.5$ & 14,445 & $-\$ 13,031$ & 0 \\
11 & 14,445 & $17,217.5$ & 0 & $2,772.5$ & 14,445 & $-\$ 13,031$ & 0 \\
12 & 14,445 & $17,217.5$ & 0 & $7,305.5$ & 9,912 & $-\$ 34,336$ & $-\$ 21,305$ \\
13 & 14,445 & $17,217.5$ & 0 & $11,838.5$ & 5,379 & $-\$ 55,641$ & $-\$ 42,610$ \\
14 & 14,445 & $17,217.5$ & 0 & $14,241.5$ & 2,976 & $-\$ 66,935$ & $-\$ 53,904$ \\
15 & 372 & 443.4 & $45,100.6$ & 0 & 45,544 & $\$ 211,972$ & $\$ 212,307$ \\
16 & 13,376 & $15,943.3$ & 0 & $2,567.3$ & 13,376 & $-\$ 12,066$ & 0 \\
17 & 34 & 40.5 & 0 & 6.5 & 34 & $-\$ 31$ & 0 \\
18 & 5,853 & $6,976.4$ & 0 & $1,123.4$ & 5,853 & $-\$ 5,280$ & 0 \\
19 & 2.7 & 3.2 & $1,851.8$ & 0 & 1,855 & $\$ 8,703$ & $\$ 8,705$ \\
20 & 80,004 & $95,359.5$ & 0 & $15,355.5$ & 80,004 & $-\$ 72,170$ & 0 \\
\hline Total & 251,692 & 300,000 & 101,077 & 101,077 & 300,000 & 0 & 227,047 \\
\hline
\end{tabular}

Table 5 Transactions for Case 3 where the catchment is over-allocated and initial allowances are down-scaled proportionally by $\alpha=0.59$.

\begin{tabular}{lrrrrrrr}
\hline Participant & $\begin{array}{c}\text { Initial } \\
\text { discharge } \\
\text { allowance, } \\
\mathrm{kg}\end{array}$ & $\begin{array}{c}\text { Scaled } \\
\text { allowance, } \\
\mathrm{kg}\end{array}$ & $\begin{array}{c}\text { Allowance } \\
\text { sold, kg }\end{array}$ & $\begin{array}{c}\text { Allowance } \\
\text { bought, kg }\end{array}$ & $\begin{array}{c}\text { Final } \\
\text { discharge, } \\
\mathrm{kg}\end{array}$ & $\begin{array}{c}\text { Net } \\
\text { payment } \\
\text { with } \\
\text { scaling, \$ }\end{array}$ & $\begin{array}{c}\text { Net } \\
\text { payment } \\
\text { without } \\
\text { scaling, \$ }\end{array}$ \\
\hline 1 & 603 & 359.4 & 135.6 & 0 & 495 & $\$ 1,899$ & $-\$ 1,512$ \\
2 & 603 & 359.4 & 158.6 & 0 & 518 & $\$ 2,221$ & $-\$ 1,190$ \\
3 & 3,331 & $1,985.2$ & $45,432.8$ & 0 & 47,418 & $\$ 636,064$ & $\$ 617,222$ \\
4 & 3,063 & $1,825.4$ & 548.6 & 0 & 2,374 & $\$ 7,680$ & $-\$ 9,646$ \\
5 & 14,445 & $8,608.7$ & 0 & $3,240.7$ & 5,368 & $-\$ 45,370$ & $-\$ 127,078$ \\
6 & 14,445 & $8,608.7$ & 0 & $6,817.7$ & 1,791 & $-\$ 95,448$ & $-\$ 177,156$ \\
7 & 14,445 & $8,608.7$ & 0 & $2,121.7$ & 6,487 & $-\$ 29,704$ & $-\$ 111,412$ \\
8 & 14,445 & $8,608.7$ & 0 & $5,913.7$ & 2,695 & $-\$ 82,792$ & $-\$ 164,500$ \\
9 & 14,445 & $8,608.7$ & 0 & $3,229.7$ & 5,379 & $-\$ 45,216$ & $-\$ 126,924$ \\
10 & 14,445 & $8,608.7$ & 0 & $1,037.7$ & 7,571 & $-\$ 14,528$ & $-\$ 96,236$ \\
11 & 14,445 & $8,608.7$ & 0 & $5,059.7$ & 3,549 & $-\$ 70,836$ & $-\$ 152,544$ \\
12 & 14,445 & $8,608.7$ & 0 & $4,136.7$ & 4,472 & $-\$ 57,914$ & $-\$ 139,622$ \\
13 & 14,445 & $8,608.7$ & 0 & $5,903.7$ & 2,705 & $-\$ 82,652$ & $-\$ 164,360$ \\
14 & 14,445 & $8,608.7$ & 0 & $5,632.7$ & 2,976 & $-\$ 78,858$ & $-\$ 160,566$
\end{tabular}




\begin{tabular}{lrrrrrrr}
15 & 372 & 221.7 & $19,282.3$ & 0 & 19,504 & $\$ 269,952$ & $\$ 267,848$ \\
16 & 13,376 & $7,971.6$ & $5,404.4$ & 0 & 13,376 & $\$ 75,661$ & 0 \\
17 & 34 & 20.3 & 13.7 & 0 & 34 & $\$ 192$ & 0 \\
18 & 5,853 & $3,488.2$ & 0 & 1111.2 & 2,377 & $-\$ 15,557$ & $-\$ 48,664$ \\
19 & 2.7 & 1.6 & 908.1 & 0 & 909.7 & $\$ 12,711$ & $\$ 12,693.8$ \\
20 & 80,004 & $47,679.7$ & 0 & $27,678.7$ & 20,001 & $-\$ 387,502$ & $-\$ 840,042$ \\
\hline Total & 251,692 & 150,000 & 71,884 & 71,884 & 150,000 & 0 & $-1,423,688$ \\
\hline
\end{tabular}

\section{Accepted Manuscript Not Copyedited}


Figure 1 Smart market components; P1, P2, P3 and P4 are participants who are located at different places in the catchment.

Figure 2 Impacting initial conditions and maximum capacity at control point. $\mathrm{I}_{,} \mathrm{L}_{1}$ and $\mathrm{L}_{2}$ are total sediment, and limits. Arrows represent the scaling conditions.

Figure 3 Sub-catchment schematic layout of the channel network, properties, and initial land uses for the example applications. Blue and black arrows represent channels and sediment directions respectively, and the black circle corresponds to the control point. 


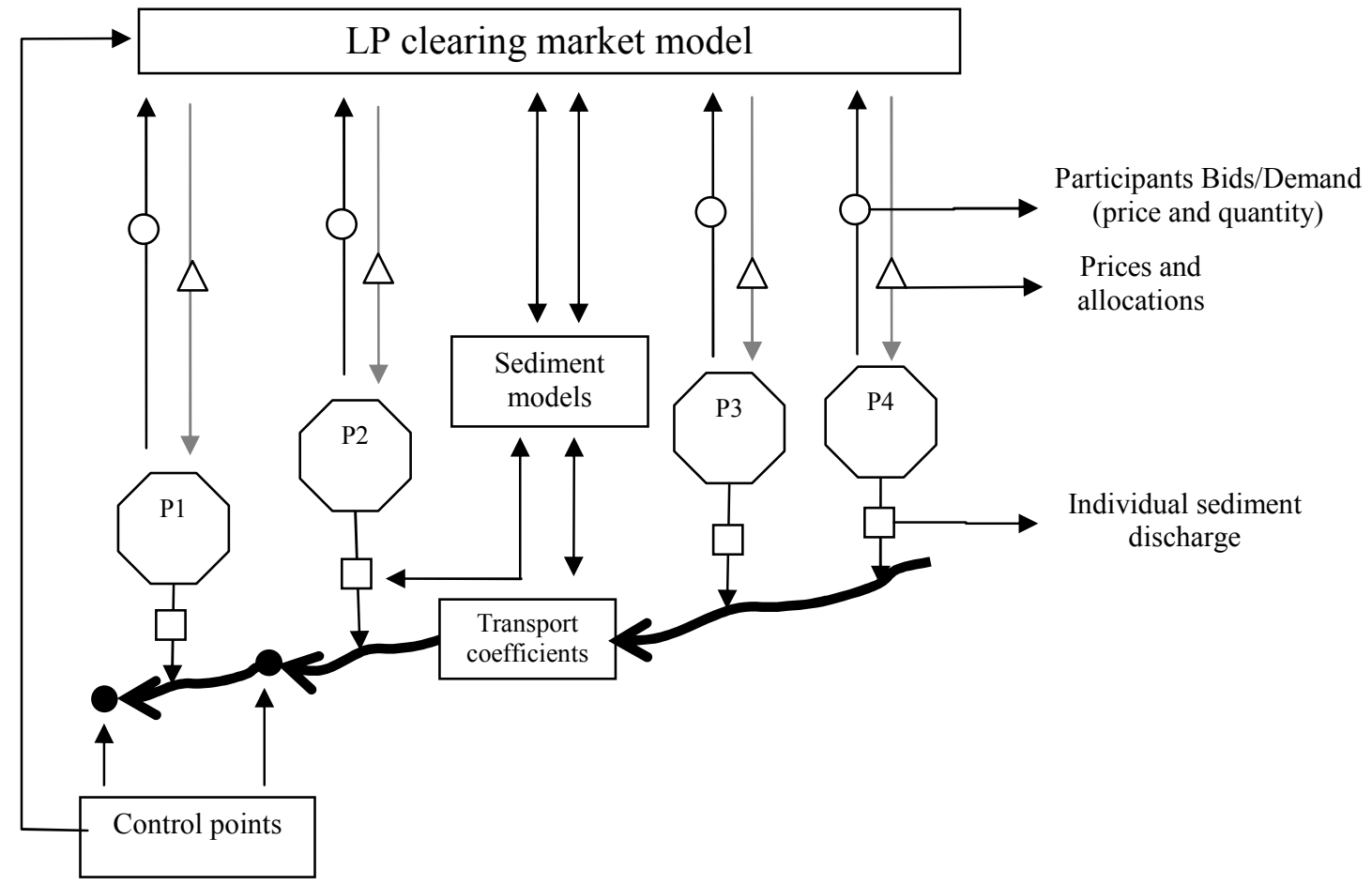

Figure 1 Smart market components; P1, P2, P3 and P4 are participants who are located at different places in the catchment.

Accepted Manuscript Not Copyedited 


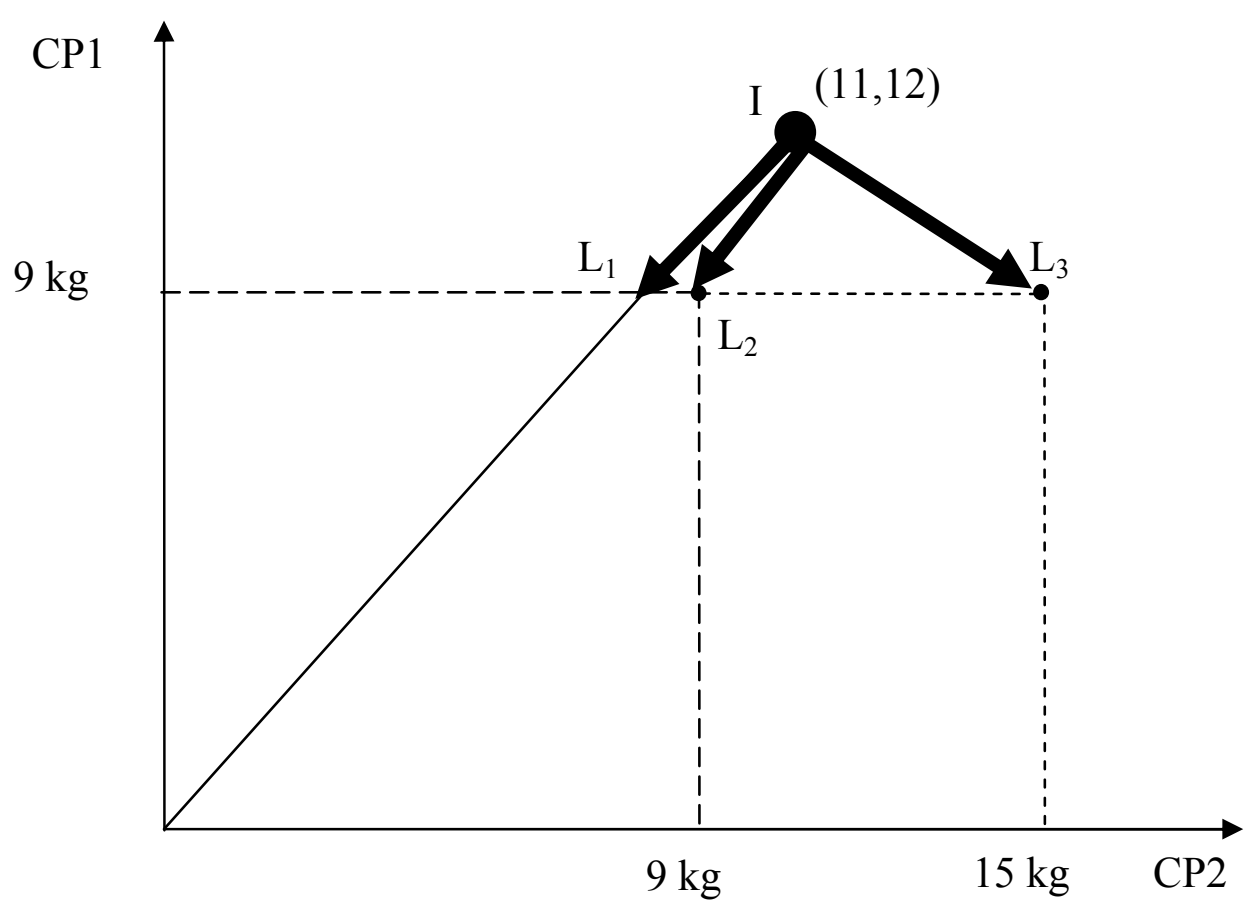

Figure 2 Impacting initial conditions and maximum capacity at control point. $\mathrm{I}, \mathrm{L}_{1}$ and $\mathrm{L}_{2}$ are total sediment, and limits. Arrows represent the scaling conditions.

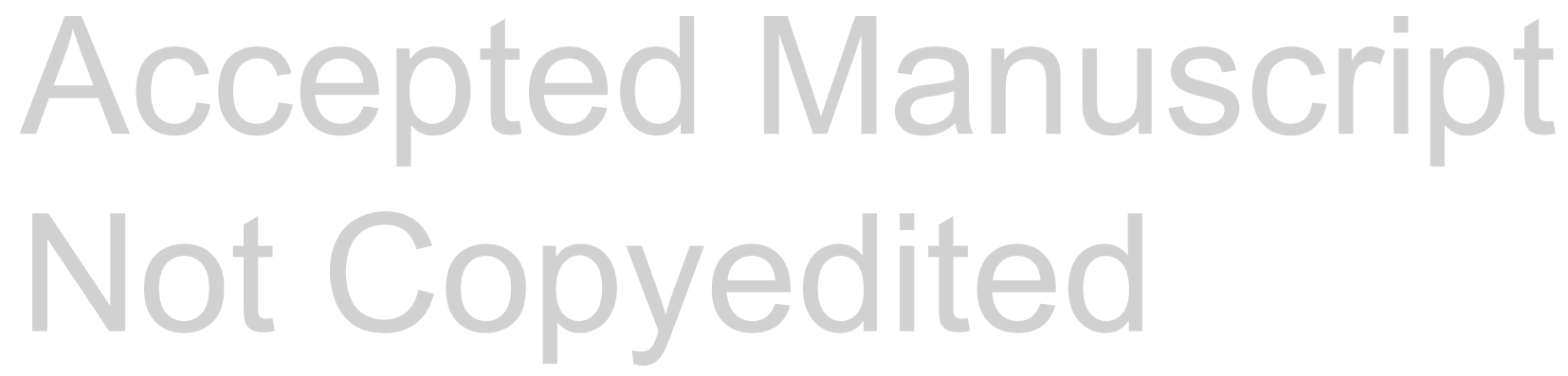




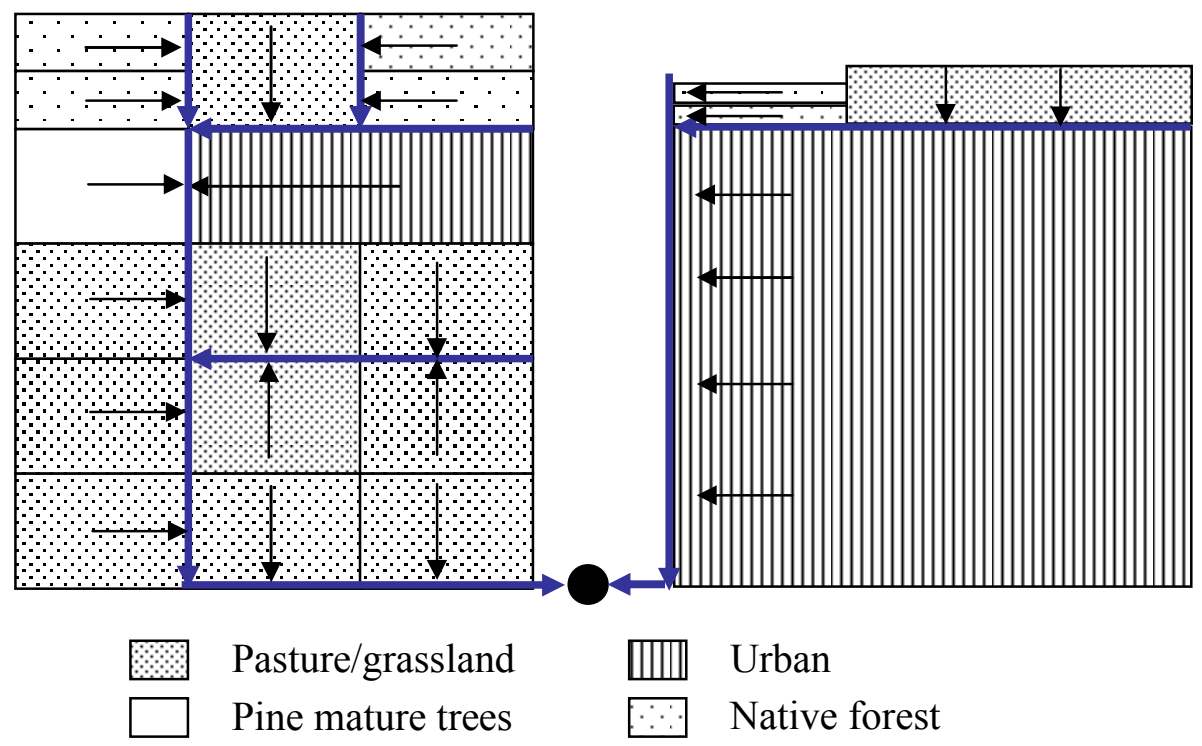

Figure 3 Sub-catchment schematic layout of the channel network, properties, and initial land uses for the example applications. Blue and black arrows represent channels and sediment directions respectively, and the black circle corresponds to the control point.

\section{Accepted Manuscript Not Copyedited}

